\title{
Involuntary Dismissal for Disobedience or Delay: The Plaintiff's Plight
}

Involuntary dismissal occasionally causes the plaintiff in a civil action to lose his case without ever receiving a trial on the merits. In most jurisdictions the trial court can dismiss a complaint if the plaintiff fails to comply with a court order or fails to prosecute his case in a diligent manner. ${ }^{1}$ Such dismissals are usually unconditional and frequently extinguish the plaintiff's cause of action. The plaintiff, however, is seldom personally responsible for the disobedience or delay in our system of representative litigation. ${ }^{2}$

In view of the harshness of unconditional dismissal, this comment considers whether a conditional dismissal-which would give the plaintiff a chance to correct his attorney's default or delay-would be a viable alternative in some of the situations where unconditional dismissal is frequently imposed. ${ }^{3}$ While dismissal may victimize an innocent plaintiff in only a few of the cases pending at any one time, the injustice seems sufficient to warrant concern.

\section{Involuntary Dismissal: A Sanction for Disobedience or Delay}

The plaintiff in a civil action has a duty to comply with court orders and to prosecute his case in a diligent manner. Breach of either duty

1 Most jurisdictions have a statute or rule of procedure which authorizes dismissal for failure to prosecute or to comply with court orders or both. See, e.g., FED. R. Crv. P. 41(b); Alaska R. Civ. P. 41(b), (e); Ariz. R. Civ. P. 41(b); Cal. Crv. Proc. Code \$§ 581, 581a, 583; FlA. R. CIv. P. 1.35(b), (e); GA. Code ANN. § 81A-141(b), (e); IND. R. CIv. P. 1-4C; Iowa R. Grv. P. 215.1; Mich. Gen. CT. R. 501.3; N.Y. Giv. Prac. Act § 3216; R.I. Gen. LAwS \$§ 9-8-3, 4, 5 (1966 Supp.); WASH. REv. CODE ANN. $\$ 4.56 .120$ (1962). Even in the absence of a statute or rule, the power to dismiss for failure to prosecute or to comply with a court order is generally considered an inherent power. See authorities cited note 14 infra.

2 See Greenwald v. Zyvith, 23 App. Div. 2d 201, 203, 259 N.Y.S.2d 387, 389 (1965) ("It would be the very unusual case where the plaintiff himself could be personally implicated in his attorney's delay.").

3 This comment does not deal with voluntary dismissal which the plaintiff may obtain if he does not wish to pursue his case. See, e.g., FED. R. Grv. P. 41(a). Nor is it concerned with involuntary dismissal for lack of jurisdiction, improper venue, or failure to join a proper party. This comment assumes that the case is properly before a court and would be tried but for failure to diligently prosecute or for disobedience of a court order. While the somewhat analogous situation where a defendant is defaulted will not be considered here, the arguments advaniced against binding the plaintiff by his attorney's pretrial neglect probably apply with equal force in the default situation. 
may result in dismissal of his complaint. Thus, if the plaintiff disobeys an order to produce documents for the court to inspect before trial ${ }^{4}$ or an order to provide defendant with a list of the witnesses he intends to call at the trial, ${ }^{5}$ the court may dismiss. While both plaintiffs and defendants are obliged to comply with court orders, the power to render an adverse judgment as a penalty for disobedience seems more restricted with respect to defendants. ${ }^{6}$

The duty to prosecute with diligence is peculiarly the plaintiff's as the party seeking relief: "no affirmative duty to do more than meet the plaintiff step by step is cast on the defendant." Dismissal may be imposed for many types of delay, such as unreasonable delay in service of process after filing the complaint, ${ }^{8}$ prolonged inactivity after joinder of issue, ${ }^{9}$ failure to amend within a reasonable time after a demurrer has

4 See Marshall v. Southern Farm Bureau Cas. Co., 36 F.R.D. 186 (W.D. La. 1964), aff'd, 353 F.2d 737 (5th Cir. 1965), cert. denied, 384 U.S. 910 (1966).

5 See Warriner v. Ferraro, 177 So. 2d 723 (Fla. App. 1965), cert. denied, 188 So. 2d 319 (Fla. Sup. Ct. 1966).

6 The Supreme Court has held that it is a denial of due process to enter a default judgment to punish a defendant for contempt. Hovey v. Elliott, 167 U.S. 409 (1897). But in a later case the Court allowed a default for disobedience to a discovery order. Hammond Packing Co. v. Arkansas, 212 U.S. 322 (1908). The former case involved "mere punishment," while the latter involved "the undoubted right of the lawmaking power to create a presumption of fact as to the ... untruth of an answer .... from the suppression or failure to produce the proof ordered ..." Id. at 350-51. Rule 37 of the Federal Rules of Civil Procedure incorporates this distinction, see Advisory CoMmirte, Notes to the Rules of Crvil Procedure for the District Courts of the United Srates 33 (1938), and allows either a dismissal or a default for willful refusal to comply with a discovery order. See Societe Internationale v. Rogers, 357 U.S. 197, 212 (1958); Oaks v. Rojewicz, 409 P.2d 839 (Alaska 1966); Developments in the Law-Discovery, 74 FARv. L. REv. 940, 990 (1961). There is, however, for defendants no counterpart to Rule 41(b) which allows a dismissal "for failure . . . to comply with . . . any court order."

7 Knight v. Pacific Gas \& Elec. Co., 178 Cal. App. 2d 923, 929, 3 Cal. Rptr. 600, 604 (1960) quoting Gunner v. Van Ness Garage, 150 Cal. App. 2d 345, 347, 310 P.2d 32, 33 (1957); accord, Abner Corp. v. Lushing, 212 Cal. App. 2d 597, 28 Cal. Rptr. 207 (1963). In this latter case plaintiff failed to have defendant's demurrer decided for 3 years. The court relied on the following language from an earlier opinion to sustain the dismissal: " 'It is true that the defendant may bring about a trial of the issue presented by his demurrer, but he is not under any duty to do so; his attitude in the case is involuntary, and quite different from that of the plaintiff; he is put to a defense only, and can be charged with no neglect for failing to do more than meet the plaintiff step by step. The plaintiff is the party charged with the duty of diligence in prosecuting the action ...." Id. at 606, 28 Cal. Rptr. at 213.

8 See, e.g., Pearson v. Dennison, 353 F.2d 24 (9th Cir. 1965); Greenwald v. Zyvith, 23 App. Div. 2d 201, 259 N.Y.S.2d 387 (1965). Delay in service of process is excusable if the defendant has secreted himself or been absent from the state so that process could not be served. See Wyoming Pac. Oil Co. v. Preston, 50 Cal. 2d 736, 329 P.2d 489 (1958); Carter v. Superior Ct., 187 Cal. App. 2d 1, 9 Cal. Rptr. 140 (1960).

9 See, e.g., Cucurillo v. Schulte, 324 F.2d 234 (2d Cir. 1963); Birdsong v. United States, 262 F.2d 105 (9th Cir. 1958); Swirsky v. Emanuel Arms, Inc., 20 App. Div. 2d 524, 245 
been sustained, ${ }^{10}$ failure to attend a scheduled pretrial conference, ${ }^{11}$ failure to appear on the day set for trial, ${ }^{12}$ or appearance at trial unprepared to proceed. ${ }^{13}$

Although dismissal for disobedience or delay is generally considered to be within the "inherent power" of courts, ${ }^{14}$ most jurisdictions have codified the power to dismiss in a statute or rule of procedure. ${ }^{15}$ Rule 41 (b) of the Federal Rules of Civil Procedure gives the district courts wide discretion to determine when they ought to dismiss..$^{16}$ Many of the district courts have adopted a local rule to supplement this general provision. ${ }^{17}$ The similarly broad New York statute ${ }^{18}$ is said to reject "the approach of enumerating specific situations that call for dismissal in favor of a flexible rule enabling the courts 'adequately to deal with the multifarious situations which might amount to want of prosecu-

N.Y.S.2d 201 (1963); Sortino v. Fisher, 20 App. Div. 2d 25, 28-29, 245 N.Y.S.2d 186, 191 (1963).

10 See, e.g., Maddox v. Shroyer, 302 F.2d 903 (D.C. Cir. 1962).

11 See, e.g., Link v. Wabash R.R., 370 U.S. 626 (1962), affirming 291 F.2d 542 (7th Cir. 1961) (the majority relied partly on the drawn-out history of the case); Wisdom v. Texas Co., 27 F. Supp. 992 (N.D. Ala. 1939).

12 See, e.g., Janousek v. French, 287 F.2d 616 (8th Cir. 1961); Ahlstrom v. City of Chicago, 73 Ill. App. 2d 264, 219 N.E.2d 657 (1966); Robertson v. Western Bearings Co., 50 Ill. App. 2d 173, 200 N.E.2d 48 (1964). But cf. Leong v. Railroad Transfer Service, Inc., 302 F.2d 555 (7th Cir. 1962) (dismissal improper where attorneys for both parties failed to appear and plaintiff would be barred by dismissal).

13 See, e.g., Joseph v. Norton Co., 273 F.2d 65 (2d Cir. 1959); Grunewald v. Missouri Pac. R.R., 331 F.2d 983 (8th Cir. 1964); Gray v. Gray, 6 Ill. App. 2d 571, 128 N.E.2d 602 (1955).

14 See Link v. Wabash R.R., 370 U.S. 626, 630-31 (1962), affirming 291 F.2d 542 (7th Cir. 1961); Surrency v. Winn \& Lovett Grocery Co., 160 Fla. 294, 297, 34 So. 2d 564, 565 (1948); 3 Nichols, Irunois Civil Practice § 2845 (1961).

15 See authorities cited note 1 supra.

16 Fed. R. Civ. P. 41(b): "For failure of the plaintiff to prosecute or to comply with these rules or any order of court, a defendant may move for dismissal of an action or of any claim against him." Although Rule $41(\mathrm{~b})$ appears to require a motion by defendant, the Supreme Court has held that it does not. Link v. Wabash R.R., 370 U.S. 626, 630 (1962), affirming 291 F.2d 542 (7th Cir. 1961).

17 Although the local rules vary, about thirty district courts have one similar to this: "Upon request of the court the clerk shall prepare and submit to the court a list of all civil actions in which no steps or proceedings appear to have been taken within six months. The court may by order provide that the attorneys in any such case be directed to show cause at a time to be fixed by the court, why the case should not be dismissed. If no satisfactory cause is shown, the court may direct the clerk to enter an order dismissing the same for want of prosecution with or without costs." W.D. Mich. R. 8. Eleven districts give a forewarning that dismissal will occur unless action is taken. See note 35 infra. Twenty-four districts do not appear to have a rule dealing with dismissal. See generally Callaghan \& Company, FeDERAL Local Gourt Rules (1964).

18 N.Y. Crv. Prac. Acr § 3216: "Where a party unreasonably neglects to proceed in the action against any party who may be liable to a separate judgment, the court, on its own initiative or upon motion, may dismiss the party's pleadings on terms . ..." 
tion ... . "19 Other jurisdictions control the courts' power to dismiss either by precluding dismissal unless certain conditions obtain, ${ }^{20}$ or by making dismissal mandatory in specified circumstances. ${ }^{21}$ California enumerates several situations, making dismissal discretionary in some and mandatory in others. ${ }^{22}$ Apart from whatever limitations the statutes or rules may impose, dismissal is largely a matter of discretion.

The legal effect of a dismissal for disobedience or delay varies from one jurisdiction to another. In the absence of a statute or rule to the contrary, it is usually held that such a dismissal is not res judicata because it is not an adjudication on the merits. ${ }^{23}$ In New York this holds true unless the court in its order of dismissal specifies otherwise. ${ }^{24}$ "Ordinarily, then, so long as the statute of limitations has not run, the plaintiff may simply pick up his papers after being dismissed ... and commence a new action." 25 The federal rule, on the other hand, provides that unless the court specifies otherwise a dismissal for disobedience or delay "operates as an adjudication on the merits" and therefore bars the plaintiff. ${ }^{26}$

Even where dismissal is not considered res judicata, the plaintiff

194 Weinstein, Korn \& Miller, New York Civir Practice If 3216.01 (1965).

20 See, e.g., Maine R. Civ. P. 41(b). Under this rule a case cannot be dismissed for want of prosecution unless it has been inactive for two years. Commentators suggest, however, that where the delay has been less, the defendant might "ask the court for an order that the plaintiff proceed to trial. If he then does not, the action may be dismissed ... for noncompliance with an order of court." Field \& McKasick, Maine Civil Practice § 41.6 (1959).

21 See, e.g., N.M.R. Civ. P. $41($ (e)(1). The New Mexico rule provides that a defendant can have any claim dismissed where the plaintiff has failed "to take any action . . . for a period of at least three years." Dismissal is discretionary for a lesser delay.

22 CAL. Crv. Prac. Code $\S \S 581,581 a, 583$. Section 583 provides that dismissal is discretionary "whenever the plaintiff has failed for two years after the action is filed to bring such action to trial," and mandatory "unless such action is brought to trial within five years." Section 581a provides that dismissal is mandatory "unless summons shall have issued within one year, and all such actions must be in like manner dismissed, unless the summons shall be served and return thereon made within three years." And § 581 provides that dismissal is discretionary "when either party fails to appear on the trial and the other party appears and asks for such dismissal."

23 See, e.g., Mattern v. Carberry, 186 Cal. App. 2d 570, 572, 9 Cal. Rptr. 137, 139 (1960). See generally Annot., Dismissal of Civil Actions for Want of Prosecution as Res Judicata, 54 A.L.R.2d 473, 478 (1957).

24 N.Y. Civ. Prac. ACT \$ 3216.

254 WEINSTEIN, KorN \& MrLLER, op. cit. supra note 19 , at $₫ 3216.15$.

26 FED. R. Crv. P. 41(b). This provision is both a canon of construction which determines the legal effect of an order of dismissal which is silent on that point, see Pearson $\mathrm{v}$. Dennison, 353 F.2d 24, 27 (9th Cir. 1965), and a source of authority which district courts previously did not have. See Miller v. Standard Oil Co., 104 F. Supp. 946,948 (N.D. Ill. 1952). A few of the district courts in their local rules provide that "such dismissal shall be without prejudice." C.D. CAL. R. 10; S.D. Gat. R. 10; Mass. R. 12; W.D.N.Y.R. 11. Most local rules, however, are silent on this point. 
is generally barred from bringing his action again if the statute of limitations has run while the dismissed action was pending. ${ }^{27}$ Illinois gives the plaintiff whose case has been dismisssed one year within which to bring a new action even though the statute has run. ${ }^{28}$ This approach, however, is rare. ${ }^{29}$ Thus, the statute of limitations often performs the function of res judicata in those jurisdictions where dismissal is not a bar in itself. ${ }^{30}$

Dismissal can be ordered by the court on its own initiative or on a motion by defendant. ${ }^{31}$ Although the Supreme Court has held that procedural due process does not require notice and hearing before a complaint is dismissed for want of prosecution, ${ }^{32}$ prior notice and hearing are frequently given..$^{33}$ If not, the plaintiff can file a motion to vacate the dismissal and get a hearing in that way. ${ }^{34}$. A few courts warn the attorneys where no recorded action has been taken for six months or a year that the case will be dismissed unless some action is taken within a short period of time. ${ }^{35}$ Such rules, however, are uncommon.

27 See Bomer v. Ribicoff, 304 F.2d 427, 429 (6th Cir. 1965).

28 Ill. Rev. Stat. ch. 83, \& 24a (1966). But see Tidwell v. Smith, 57 Ill. App. 2d 271, 205 N.E.2d 484 (1965) (if the delay which leads to dismissal is deliberate, the plaintiff cannot claim the statutory extension); of. Williams v. Pearson, 28 Ill. App. 2d 210, 171 N.E.2d 250 (1960).

29 Many states do not have statutes which extend the limitations period where an action has been dismissed before reaching the merits: e.g., Alabama, Arizona, California, Colorado, Florida, Idaho, Washington, and Wisconsin. Some states which have such a statute expressly exclude dismissals for lack of diligence. See, e.g., IND. ANN. STAT. § 2-608 (1946); Iowa Code $\$ 614.10$ (1962); N.Y. Crv. PRAc. ACT $\$ 205(a)$. In some states where the statute does not expressly make an exception, the courts have supplied it. See, e.g., Cummings v. Jacobs, 130 Mass. 419, 421 (1881); Lawrence v. Winifrede Coal Co., 48 W. Va. 139, 142, 35 S.E. 925, 926 (1900). Some states, however, do appear to follow the Illinois approach. See, e.g., Conn. Gen. Stat. ANN. § 52-599 (1960); DeL. Code ANN. § 8117 (1953); GA. Code ANn. \$ 3-808 (Supp. 1962); OHro Rev. Code ANN. \$ 2305.19 (Page rev. 1953).

30 Especially where the dismissal is for prolonged inactivity, the statute will often have run by the time the case is dismissed.

31 See, e.g., authorities cited notes 16-18 supra.

32 Link v. Wabash R.R., 370 U.S. 626, 633 (1962), affirming 291 F.2d 542 (7th Cir. 1961). Mr. Justice Black argued in dissent that the plaintiff's cause of action is property and that "due process requires that property shall not be taken away without notice and hearing." $I \vec{d}$. at 646 . At least two state courts have agreed with Mr. Justice Black, holding that procedural due process requires prior notice to the plaintiff. See W. M. Crysler Co. v. Smith, 377 S.W.2d 134 (Mo. App. 1964); Latham v. Casey \& King Corp., 23 Wis. 2d 311, 127 N.W.2d 225 (1964).

33 Many courts periodically call all cases in which no recorded activity has been taken for six months or one year. Notice is sent to the attorneys of record. If plaintiff's attorney either fails to appear at the specified time or appears without an adequate excuse for the delay, the case may be dismissed. See, e.g., IND. R. Crv. P. 1-4C; Iowa R. Civ. P. 215.1; authorities cited note 17 supra.

34 See, e.g., Wojton v. Marks, 344 F.2d 222 (7th Cir. 1965); Leong v. Railroad Transfer Service, Inc., 302 F.2d 555 (7th Cir. 1962).

35 Eleven federal district courts have a local rule which provides for such a warning. 
The burden of excusing unreasonable delay is on the plaintiff. Generally, a good excuse must be something beyond the control of both the plaintiff and his attorney, such as serious illness of plaintiff's attorney, ${ }^{36}$ repeated hospitalizations of plaintiff, ${ }^{37}$ or forced absence of plaintiff from the state when the case is called for trial. ${ }^{38}$ But conflicting engagements, press of other business, misplacement of the case's file, and ignorance of the court's rules have been held to be inadequate excuses. ${ }^{30}$ The conduct of the defendant is irrelevant unless he has affirmatively contributed to the delay. ${ }^{40}$

That the plaintiff himself has been free from neglect is usually not considered important if his attorney has inexcusably failed to prosecute his case in a diligent manner. In Link v. Wabash Railroad, ${ }^{41}$ where the Supreme Court in a divided opinion affirmed a dismissal for failure of plaintiff's attorney to attend a scheduled pretrial conference, Mr. Justice Harlan for the majority said: "Petitioner voluntarily chose this attorney as his representative in the action ${ }_{b}$ and he cannot now avoid the consequences of the acts or omissions of this freely selected agent. Any

D. CoNN. R. I5; D.C.R. 13; S.D. IND. R. 16; D. KAN. R. 17(a); D.N.M.R. 13; W.D.N.Y.R. 11; E.D. OKLA. R. 29; N.D. OKLA. R. 30; M.D. PA. R. 21-A; E.D. WASH. R. 11; D. WYo. R. 14.

36 See Deluccy v. City of New York, 24 App. Div. 2d 421, 260 N.Y.S.2d 191 (1965); Thorn v. Borough of Clearfield, 420 Pa. 584, 218 A.2d 298 (1966). But cf. Valentin v. Ina Holding Corp., 20 App. Div. 2d 525, 245 N.Y.S.2d 206 (1963).

37 See DeRosa v. Nezelek, 24 App. Div. 2d 1055, 265 N.Y.S.2d 559 (1965).

38 See Heidman v. Kelsey, 3 Ill. App. 2d 189, 121 N.E.2d 45 (1954).

39 See Ohliger v. United States, 308 F.2d 667 (2d Cir. 1962) (ignorance of court's rules no excuse); Ahlstrom v. City of Chicago, 73 Ill. App. 2d 264, 219 N.E.2d 657 (1966) (conflicting engagement no excuse); Bradley v. City of New York, 24 App. Div. 2d 490, 261 N.Y.S.2d 406 (1965) (misplacement of case's file no excuse); Flannery v. Stewart, 22 App. Div. 2d 786, 254 N.Y.S.2d 130 (1964) (inability to confer with counsel due to business commitments no excuse).

Conflicting engagements caused by a concentration of many pending cases among a small number of the bar seem to create a serious problem. See Gray v. Gray, 6 Ill. App. 2d 571, 576, 128 N.E.2d 602, 605 (1955). Cf. ZEISEL, KALVEN \& BuchHolz, DeLAX IN THE CourT 192-98 (1959), where the authors suggest "simply that the Court in scheduling recognize the concentration as a fact of life and seek to accommodate it." An excuse frequently proferred in dismissal proceedings is some type of clerical error or oversight in the office of plaintiff's attorney. One author on delay in the courts writes "that lawyers, as a group, are notoriously inefficient in the management of their offices ... [and that] a poorly ordered law office may contribute substantially to delay causing calendar congestion ...." Miller, A Program for the Elimination of the Hardships of Litigation Delay, 27 OHro ST. L.J. 402, 420 (1966). Also, there is the natural tendency to procrastinate. See Bardin v. Mondon, 298 F.2d 235, 237 n.5 (2d Cir. 1961).

40 See Foxboro Co. v. Fisher \& Porter Co., 29 F.R.D. 522 (E.D. Pa. 1961); Brown v. Weissberg, 22 App. Div. 2d 282, 283, 254 N.Y.S.2d 628, 630 (1964).

41370 U.S. 626 (1962), affirming 291 F.2d 542 (7th Cir. 1961). 
other notion would be wholly inconsistent with our system of representative litigation ...." 42 Most states appear to follow this view. ${ }^{43}$

Although "one of the factors properly considered by the court in exercising its discretion [is] the effect of delay upon the adverse party,"44 it is usually held that the defendant need not have been prejudiced by the delay. ${ }^{45}$ The courts in the Second Department in New York have been reluctant to dismiss where the statute of limitations has run and the defendant has not been prejudiced by previous delay. Under these circumstances dismissal may be denied with a proviso that diligence be exercised henceforth. ${ }^{46}$ Justice Breitel of the First Department, on the other hand, has argued that the running of the statute is usually an indication that the claim has become too stale to litigate and that therefore it ought to be dismissed. ${ }^{47}$

In most jurisdictions the only inquiry in a hearing on a motion to dismiss for want of prosecution seems to be whether the delay was excusable or not. New York courts are consequently peculiar in that they consider the probable merit of plaintiff's claim. In order to defeat a motion to dismiss for delay, the plaintiff must produce an affidavit of merits establishing that he has a viable cause of action. ${ }^{48}$ The theory is that many neglected cases are lacking in merit and are purposefully delayed to keep their settlement value alive. ${ }^{49}$ If the plaintiff can show that his claim has probable merit, this may offset admittedly weak excuses for delay ${ }^{50}$ and perhaps even the absence of an excuse. ${ }^{51}$ On the other hand, a good excuse may not suffice without an affidavit of merits. ${ }^{\mathbf{5}}$

$42 I d$. at 633-34. Justices Black, Dóuglas, and Warren dissented. For a discussion of Mr. Justice Black's dissenting opinion, see text accompanying notes 56-60 infra.

43 See, e.g., Ayers v. D. F. Quillen \& Sons, Inc., 188 A.2d 510, 511 (Del. Sup. Ct. 1963); Sortino v. Fisher, 20 App. Div. 2d 25, 29, 245 N.Y.S.2d 186, 192 (1963). Most courts accept this proposition without discussion.

44 Hanson v. Firebaugh, 87 Idaho 202, 207, 392 P.2d 202, 206 (1964).

45 Messenger v. United States, 231 F.2d 328, 331 (2d Cir. 1956); Sprajc v. Scandinavian Airlines, Inc., 240 Cal. App. 2d 935, 939, 50 Cal. Rptr. 181, 183 (1966); Sortino v. Fisher, 20 App. Div. 2d 25, 32, 245 N.Y.S.2d 186, 195 (1963); Bock v. Portland Gas \& Coke Co., 202 Ore. 609, 616, 277 P.2d 758, 762 (1954). However, the Ninth Circuit has reversed dismissals where the delay has been slight with leave to reconsider if the defendant can show that he has been prejudiced by the delay. See Sykes v. United States, 290 F.2d 555 (9th Cir, 1961); Jarva v. United States, 280 F.2d 892 (9th Cir. 1960).

46 See, e.g., Tricario v. Kahan, 236 N.Y.S.2d 173, 174 (Sup. Ct. 1962); cf. Dooley v. Gray, 22 App. Div. 2d 791, 253 N.Y.S.2d 808 (1964).

47 See note 80 infra. See generally 4 WEINSTEIN, KORN \& MIILER, op. cit. supra note 19, \$ 3216.14, on the contrariety of views between the First and Second-Departments.

48 Sortino v. Fisher, 20 App. Div. 2d 25, 32, 245 N.Y.S.2d 186, 194-95 (1963).

49 Id. at 28,245 N.Y.S.2d at $190-91$.

50 See Friedman v. Fortgang, 21 App. Div. 2d 779, 250 N.Y.S.2d 862 (1964).

51 See Giodano v. St. Clare's Hosp., 24 App. Div. 2d 568, 569, 262 N.Y.S.2d 61, 62 (1965).

52 See DeRosa v. Nezelek, 24 App. Div. 2d 1055, 265 N.Y.S.2d 559 (1965). 
Thus, although the practice varies, involuntary dismissal is often employed to encourage compliance with court orders and diligent prosecution. Such dismissals frequently destroy the plaintiff's cause of action either because of res judicata or because the statute of limitations has run. Even though the plaintiff has been innocent himself, the dilatory or disobedient conduct of his attorney may terminate his case before trial on the merits.

\section{Conditional Dismissal: An Alternative Approach}

Unconditional dismissal is a harsh sanction to impose for disobedience or delay, particularly where, as is generally the case, the plaintiff himself has been free from neglect. ${ }^{53}$ The objectives of involuntary dismissal are efficiency and fairness to defendants. But courts often dismiss where fairness to the defendant does not dictate the result, and where a conditional dismissal, allowing the innocent plaintiff a chance to correct his attorney's default or delay, might often be used without much sacrifice in efficiency. For deterrent effect a sanction can be imposed directly upon the negligent attorney.

\section{A. The Agency Rationale}

While there is much authority for the rule of Link $v$. Wabash Railroad $^{54}$ that counsel's neglect is imputed to his client, ${ }^{55}$ a strong argument against indiscriminate application of this rule in the pretrial context was advanced by Mr. Justice Black in dissent.

According to Mr. Justice Black, "to impose the punishment for the lawyer's failure to prosecute on the plaintiff who ... was simply trusting his lawyer to take care of his case as clients generally do" is to ignore "the practicalities and realities of the lawyer-client relationship." law is complex and the plaintiff is usually a layman; as a practical matter, he cannot supervise his attorney. The unsophisticated plaintiff may have chosen an unreliable lawyer by chance; ${ }^{57}$ he may rely to some

53 See note 2 supra.

54 See text accompanying note 43 supra.

55 See Schleiger v. Schleiger, 137 Colo. 279, 324 P.2d 370 (1958); Hale v. Wheeler, 264 Mass. 592, 593, 163 N.E. 178, 179 (1928); 2 MecheM, AGENcy \$ 2161, at 1737 (2d ed. 1914); I ThORTON, AtroRneys At LAW \$ 246, at 451 (1914). The rule is often applied with harsh results. See, e.g., Baufort Concrete Co. v. Atlantic States Constr. Co., 352 F.2d 460 (5th Cir. 1965), cert. denied, 384 U.S. 1004 (1966); Texas Employers Ins. Ass'n v. Wermske, 162 Tex. 540, 349 S.T.2d 90 (1961).

56370 U.S. at $643,646$.

67 The corporate or businessman plaintiff will often have a continuing relationship with a proficient law firm which will prosecute its case diligently to retain its patronage. The principle of caveat emptor is less appropriate with respect to the unsophisticated, individual plaintiff who is rarely involved in litigation. 
extent on the fact that states license attorneys. A long period often passes before lawsuits are tried (if the plaintiff is unaware of this, his attorney will probably inform him) ${ }^{58} \mathrm{It}$ is natural for the plaintiff to assume that his lawyer will take care of his case during this waiting period. ${ }^{59}$ From these considerations, Mr. Justice Black concluded that the plaintiff should be given prior notice that dismissal is imminent, and an opportunity to correct his attorney's default or delay before the sanction is imposed. ${ }^{60}$

Mr. Justice Black would apparently protect only the innocent plaintiff. Outright dismissal would probably be justifiable where the plaintiff's own neglect caused the delay, ${ }^{61}$ or where the plaintiff has participated in his attorney's misconduct. ${ }^{62}$ Also, in some cases the delay might be so long that the plaintiff's acquiescence would amount to neglect. But the plaintiff should be given a chance to show that reliance upon his attorney was reasonable. ${ }^{63}$

One argument against Mr. Justice Black's position is that a plaintiff who is barred because of his attorney's negligence may have a cause of action against his attorney for malpractice. ${ }^{64}$ If the plaintiff can prove that he would have recovered from the original defendant but for his attorney's neglect, he can probably recover from his attorney in a second lawsuit: ${ }^{65}$ But the malpractice remedy is not without its difficulties: in

58 See Dirton v. McCarthy, 23 Conn. Sup. 384, 184 A.2d 69 (1962). Immediately after the accident, plaintiff retained an attorney who filed a complaint and told her to forget about the matter since it would not be tried for at least three years. Then he forgot about it himself. Sometime later, plaintiff learned that her complaint had been dismissed for failure to prosecute and that her attorney had resigned from the bar.

59 See Daley v. County of Butte, 227 Cal. App. 2d 380, 392, 38 Cal. Rptr. 693, 700-01 (1964).

60370 U.S. at 648 . See Mr. Justice Black's dissenting statement from the Supreme Court's approval of the 1966 amendments to the federal rules in Moore, Federal Practice Rules Pamphlet 4 (1966).

61 See, e.g., Demeulenaere v. Rockwell Mfg. Co., 312 F.2d 209 (2d Cir. 1962); Askew v. Rose Joy Corp., 25 App. Div. 2d 679, 269 N.Y.S.2d 153 (1966).

62 See Esteva v. House of Seagram, Inc., 314 F.2d 827 (7th Cir. 1963). Plaintiff's lawyer requested an adjournment on the ground that his client, who was in court and whom he intended to put on the stand at that time, was sick. The court granted the adjournment, noting prior delays, and warned both the plaintiff and his lawyer that they should be ready to proceed the next day. Neither appeared and the case was dismissed.

63 See L. P. Steuart, Inc. v. Matthews, 329 F.2d 234 (D.C. Cir. 1964).

64 See, e.g., O’Neill v. Gray, 30 F.2d 776 (2d Cir.), cert. denied, 279 U.S. 865 (1929); Campbell v. Magana, 184 Cal. App. 2d 751, 8 Cal. Rptr. 32 (1960); Warwick, Paul \& Warwick v. Dotter, 190 So. $2 d 596$ (Fla. Dist. Ct. App. 1966); cf. Sitton v. Clements, 257 F. Supp. 63 (E.D. Tenn. 1966).

65 See Comment, Attorney Malpractice, 63 Colum. L. REv. 1292, 1307 (1963). At one time an attorney's neglect which caused a dismissal did not always establish a cause of action for malpractice: "The early cases frequently stated that the attorney is liable only for gross negligence...." Wade, The Attorney's Liability for Negligence, 12 VAND. 
some cases plaintiff's attorney may be unable to satisfy the judgment whereas the original defendant could have done so; $^{66}$ in others the plaintiff may be unaware of this remedy and may inadvertently bear the loss even though it could have been shifted. Moreover, in most cases the prosecution of a malpractice suit (as opposed to continuation of the original case) would involve additional expense, inconvenience, and delay. Only plaintiffs with sizable claims may have the forebearance to start all over again. Therefore, while the availability of a malpractice suit may theoretically justify the present law, in practice this justification falls short.

The rule that the client is bound by his attorney's neglect is strictly applied where a trial has already been held. ${ }^{67}$ The policy in favor of finality is thought to require this result. ${ }^{68}$ But relaxation of the rule in the dismissal context would not appear to be "wholly inconsistent with our system of representative litigation," as the majority suggested in $\operatorname{Link}_{,}{ }^{69}$ for the rule is often relaxed where a lawyer's neglect would

L. REv. 755, 760 (1959). Today ordinary negligence will suffice. Id. at 761. And the fact that the plaintiff's case has been dismissed because of his lawyer's neglect seems to be sufficient to get him over the first hurdle in a malpractice suit. See Hutcheson, Lawyers, How Is Your Malpractice? 30 INs. Counser J. 423 (1963).

The second hurdle in a malpractice suit-i.e., showing that the plaintiff would have recovered from the original defendant-will probably be more difficult for the plaintiff to overcome. His original attorney will ordinarily be in the best position to prove his case, since he has presumably been working on it since its inception. Without his cooperation any new attorney hired by the plaintiff will be confronted with the task of building a case that has been obscured by the passage of time.

66 of course, the original defendant may have been insolvent too. But the lawyer can plead this as a defense in the malpractice suit. See Comment, supra note 65, 63 CoLum. L. REv. at 1308. The additional risk of insolvency that the plaintiff faces in the malpractice suit may be substantial, depending on the size of the claim; and there is no guarantee that the attorney will be covered by malpractice insurance. Several states and local bar associations maintain clients' security funds, see Note, The Disenchanted Client $v$. The Dishonest Lawyer: Where Does the Legal Profession Stand? 42 Notre DAME LAW. 382, 391 (1967); but "malpractice ... [is] not within the purview of a client's security fund. While the states use differing language it is clear that all of the funds have the same purpose, to provide protection against lawyers' defalcations." Id. at 392.

67 See, e.g., Wheiles v. Aetna Life Ins. Co., 68 F.2d 99 (5th Cir. 1934); Duffy v. Griffith Co., 206 Cal. App. 2d 780, 24 Cal. Rptr. 161 (1962).

68 "Litigation would never come to an end if parties were permitted thus to shift their entire ground of attack or defense, after finding out where the pinch of the cause lay." Putnam v. Day, 89 U.S. (22 Wall.) 60,64 (1874).

69 The majority in Link relies on three criminal cases where certain omissions of defendant's attorneys were held to be binding on them. United States ex rel. Reid v. Richman, 295 F.2d 83 (2d Cir. 1961); Egan v. Teets, 251 F.2d 571 (9th Cir. 1957); United States v. Sorrentino, 175 F.2d 721 (3d Cir. 1949). From these cases the majority concludes: "Surely . . . a civil plaintiff may be deprived of his claim if he failed to see to it that his lawyer acted with dispatch ...." 370 U.S. at 634 n.10.

But while it is true that courts are reluctant to reverse convictions because of alleged 
otherwise preclude a party from receiving a trial on his claim or defense. For example, several courts liberally grant defendants relief from default judgments which have been entered because of their attorneys' neglect; ${ }^{70}$ similarly, some courts are reluctant to apply the agency rule where plaintiffs' lawyers have neglected to prosecute their claims. ${ }^{71}$ Although finality in litigation may require a rigid rule where a trial has already been held, the agency rule can probably be relaxed in the dismissal context without too much inefficiency or unfairness to defendants. In view of the losses which may be imposed upon innocent plaintiffs, an alternative solution should be sought.

\section{B. Fairness to Defendants}

One purpose of involuntary dismissal is to protect defendants from protracted litigation. Avoidable delay in prosecuting a lawsuit may be harmful to a defendant in several ways: legal expenses may be increased, defenses may become more difficult to establish, and the psychological costs of litigation are prolonged. In some cases the plaintiff might intentionally delay to induce the defendant to settle a claim which has little or no merit. But fairness to the defendant does not require unconditional dismissal in every case where plaintiff's attorney has inexcusably failed to prosecute his case diligently.

1. Monetary Costs. The dilatory conduct of plaintiff's attorney often increases defendant's legal expenses. This may be true, for example, where defendant's lawyer appears at trial prepared to proceed, and plaintiff's lawyer either fails to appear or appears unprepared to pro-

shortcomings of counsel, see Mitchell v. United States, 259 F.2d 787 (D.C. Gir. 1958); In re Beaty, 64 Cal. 2d 760, 764, 414 P.2d 817, 819, 51 Cal. Rptr. 521, 523 (1966), a distinction seems to be drawn between tactical decisions which may have been wrong, see Henry v. Mississippi, 379 U.S. 443, 451-52 (1965), and mistakes which are due to counsel's failure to prepare a defense, see Brubaker v. Dickson, 310 F.2d 30 (9th Cir. 1962); People v. Ibarra, 60 Cal. 2d 460, 368 P.2d 487, 34 Cal. Rptr. 863 (1963). See generally Note, Effective Assistance of Counsel, 49 VA. L. REv. 1531 (1963). The cases with which this comment is concerned are much more analogous to the situation where a criminal defendant's lawyer fails to prepare and therefore inadequately represents his client, than the situation where the lawyer makes a deliberate, strategic decision which may have been wrong. Therefore, the criminal analogy is not persuasive authority for binding the plaintiff in the dismissal context.

70 See, e.g., Barber v. Tuberville, 218 F.2d 34 (D.C. Cir. 1954); Coconino Pulp \& Paper Co. v. Marvin, 83 Ariz. 117, 317 P.2d 550 (1957); Finden v. Klaas, 268 Minn. 268, 128 N.W.2d 748 (1964); Brown v. Hale, 259 N.C. 480, 130 S.E.2d 868 (1963); Ackerman v. Burgard, 79 S.D. 119, 109 N.W.2d 10 (1961).

71 See, e.g., L. P. Steuart, Inc. v. Matthews, 329 F.2d 234 (D.C. Cir. 1964); Daley v. County of Butte, 227 Cal. App. 2d 380, 38 Cal. Rptr. 693 (1964); Cole v. Blair, 45 Misc. 2d 272, 256 N.Y.S.2d 712 (1964); Manekofsky v. Baker, 92 R.I. 378, 169 A.2d 376 (1961). 
ceed. ${ }^{72}$ But these costs can be assessed against either the plaintiff ${ }^{73}$ or his attorney if he is at fault. In Bardin v. Mondon ${ }^{74}$ plaintiff's attorney was inexcusably unprepared on the day set for trial and refused to proceed when his motion for a continuance was denied. The district court dismissed the action with prejudice, but the Second Circuit modified the order to read without prejudice, noting that the statute of limitations had not run, and assessed $\$ 100$ against plaintiff's lawyer "for having so multiplied the proceedings as to have increased costs unreasonably." "Although a litigant is ordinarily bound by the mistakes of his counsel," the court felt "it would serve a better purpose to require counsel himself to pay for the inconveniences caused by his own dilatory conduct." 75

It would seem that any court of record could make a similar assessment where plaintiff's attorney has inexcusably protracted litigation and thereby caused the defendant to incur additional expense. ${ }^{76}$ The assessment could be enforced by conditioning continuation of the case upon payment. ${ }^{77}$ It is doubtful that plaintiff's attorney would ignore the order to pay costs and thereby subject himself to the possibility of a malpractice suit.

2. Psychological Costs. Litigation may involve many costs which cannot be accurately expressed in monetary terms. The uncertainty of the outcome may generate anxiety and in some cases inhibit the pursuit of a desired course of conduct. The inconvenience of retaining counsel, preparing a defense, responding to discovery orders, and appearing in court will be annoying. The plaintiff should not be allowed to subject the defendant to the psychological costs of litigation for a needlessly long period of time. But these costs can be limited by a conditional dismissal.

72 See Hanson v. Firebaugh, 87 Idaho 202, 392 P.2d 202 (1964).

73 See Thompson v. Hook, 18 App. Div. 2d 710, 236 N.Y.S.2d 235 (1962) (denial of motion to dismiss affirmed on condition that plaintiff pay each defendant $\$ 50$ costs).

74298 F.2d 235 (2d Cir. 1961).

75 Id. at 238. Accord, Austin Theatre v. Warner Bros. Pictures, 22 F.R.D. 302 (S.D.N.Y. 1958); United Sheeplined Clothing Co. v. Arctic Fur Cap Corp., I65 F. Supp. 193 (S.D.N.Y. 1958).

76 This would appear to be within the inherent authority of courts to discipline attorneys. See 1 Thorton, Atrorneys at Law \$ 306, at 537 (1914); Note, Civil ProcedurePower of Federal Courts to Discipline Attorneys for Delay in Pre-trial Procedure, 38 Notre Dame LAw. 158, 164-67 (1963). A few of the federal district courts have local rules dealing with sanctions. See D. IDAHo R. 23; S.D.N.Y. CALENDAR R. 16; E.D. VA. R. 21(3); W.D. WASH. R. 3(d). The Idaho rule provides that "the offending party and/or his attorney" may be subjected "to appropriate discipline, including any or a combination of the following sanctions: imposition of costs; allowance of attorneys' fees; denial of relief; contempt proceedings; and/or, suspension of offending attorney."

77 This was done in Bardin v. Mondon: "If payment is not made as directed [i.e., within 30 days], the action will be dismissed with prejudice." 298 F.2d at 238. 
A conditional dismissal is essentially a warning that certain action must be taken within a specified time or the case will be dismissed. ${ }^{78}$ If addressed to the plaintiff himself, it would put him on notice of his lawyer's dereliction and give him a chance to correct the default or delay. Since the time allowed could be fairly short, the defendant could be protected against further delay. At the same time, the plaintiff could protect his interest either by importuning his present attorney or by retaining more diligent counsel.

3. Prejudice from Delay. There may be some cases where avoidable delay in bringing a case to trial will adversely affect the defendant's ability to establish a defense. For example, physical evidence might become lost or a valuable witness for the defendant might die. In such a case the court is faced with a dilemma: either the plaintiff must suffer a dismissal, or the defendant must suffer a disadvantageous trial. The plaintiff should not be allowed to profit from his attorney's neglect. Where the defendant can show that he has been prejudiced because of avoidable delay, the complaint should be unconditionally dismissed.70 In many cases, however, the defendant may be able to prevent this type of prejudice by preparing his case early and preserving it until trial.80

4. Specious Cause of Action. Unconditional dismissal may also be proper (even though the plaintiff has not been personally negligent and the defendant has not been prejudiced by previous delay) where an unreasonable and avoidable delay has occurred, if the plaintiff's cause of action appears to be specious. Many courts believe that neglected

78 Conditional dismissals are frequently used by the federal courts to compel compliance with discovery orders. See, e.g., Gusa v. United States, 31 F.R.D. 518 (E.D.N.Y. 1963). See generally Comment, Dismissal for Failure to Attend a Pretrial Conference and the Use of Sanctions at Preparatory Stages of Litigation, 72 YALE L.J. 819, 823-27 (1963). For a discussion of how conditional dismissal might work in this context, see text accompanying notes $87-88$ infra.

79 Cf. Lally v. Kuster, 177 Cal. 783, I71 Pac. 961 (1918). Plaintiff's attorney, anticipating a strong defense, purposefully delayed in the hope that defendant's primary witness would soon die. Unconditional dismissal where the defendant has been prejudiced by unreasonable delay would prevent the success of this type of strategy.

80 In Sortino v. Fisher, 20 App. Div. 2d 25, 30, 245 N.Y.S.2d 186, 193 (1963), Justice Breitel argued that the fact that the statute of limitations had run was a factor favoring unconditional dismissal. But the policy behind the statute of limitations is not that cases be tried within the period allowed: "The important consideration is that, by invoking judicial aid, a litigant gives timely notice to his adversary of a present purpose to maintain his rights . . . Gaines v. City of New York, 215 N.Y. 533, 539, 109 N.E. 594, 596 (1915) (Cardozo, J.). "A defendant who is promptly served may well be able to protect himself against these possibilities." Pearson v. Dennison, 353 F.2d 24, 28 (9th Cir. 1965). He cannot keep witnesses alive; but he can keep track of live witnesses and preserve evidence and even memories until trial. If a defendant has not been significantly prejudiced by delay, unconditional dismissal seems harsh, especially where the statute of limitations has run. 
actions frequently lack merit and are kept alive to compel settlements. ${ }^{81}$ This type of extortion can be guarded against by requiring that the plaintiff produce an affidavit of merits in a hearing on a motion to dismiss for delay, and by unconditionally dismissing where the delay is unexcused and plaintiff's cause of action appears to be specious. ${ }^{82}$ The unfairness of unconditional dismissal to an innocent plaintiff is considerably less where he is unable to support the allegations in his complaint.

In summary, unconditional dismissal may be proper where (a) the plaintiff himself has been negligent, (b) the defendant has been prejudiced by unreasonable delay, or (c) an unreasonable delay has occurred and plaintiff's cause of action appears to be specious. In other cases, even though plaintiff's attorney has failed to prosecute his claim in a diligent manner, conditional dismissal could be used without much unfairness to the defendant. If the defendant has incurred costs because of previous delay, reimbursement can be ordered by the court. This approach would be fairer to the plaintiff than current practice, for courts seldom seem to consider whether the plaintiff has been innocent ${ }^{83}$ the defendant has been prejudiced, ${ }^{84}$ or the cause of action has merit. ${ }^{85}$ It remains to be considered whether this approach would cause a loss of efficiency.

\section{Administrative Efficiency}

The major objective of involuntary dismissal is probably efficiency. In Link v. Wabash Railroad the Court said: "The power to invoke this sanction is necessary in order to prevent undue delays in the disposition of pending cases and to avoid congestion in the calendars of the District Courts."se Unconditional dismissal clears dockets of troublesome cases and deters dilatory and disobedient conduct on the part of plaintiffs' attorneys. But the present law may not promote efficiency much more than the system suggested in this comment.

1. Clearing the Dockets. When a complaint is conditionally dismissed, the plaintiff himself, as well as his attorney, should be given notice. ${ }^{87}$ In the case of noncompliance with a previous court order, the

81 See, e.g., Boling v. United States, 231 F.2d 926, 928 (9th Cir. 1956); Sortino v. Fisher, 20 App. Div. 2d 25, 28, 245 N.Y.S.2d 186, 190 (1963).

82 As noted above, the New York practice requires that plaintiff produce such an affidavit in a hearing on a motion to dismiss. See text accompanying notes $48-52$ supra. 83 See notes $42-43$ supra and accompanying text.

84 See note 45 supra.

85 New York appears to be the only jurisdiction that consistently considers this factor. 86370 U.S. at $629-30$.

87 Notice to an attorney who has been neglecting his client's case that dismissal may result falls too often on deaf ears. See, e.g., L. P. Steuart, Inc. v. Matthews, 329 F.2d 234 
conditional dismissal should specify a reasonable time within which the order must be obeyed. If the problem is prolonged inactivity, it should specify a reasonable time within which the case must be ready for trial. Where plaintiff's attorney fails to make a scheduled appearance or appears unprepared to proceed, it should specify a reasonable time within which the case must be reset for trial or pretrial proceedings. ${ }^{88}$ The conditional dismissal should indicate that it will automatically become final unless the conditions are satisfied within the period allowed. Conditional dismissal would clear the dockets of some casesmainly those which the plaintiffs themselves have abandoned. Otherwise, it would get the case moving again.

While unconditional dismissal often eliminates the case upon which it operates, ${ }^{89}$ there are collateral costs: the chagrined plaintiff who is barred because of his attorney's neglect often prosecutes an appeal; $; 0$ if that fails, the dismissed action may be replaced with a malpractice suit. ${ }^{91}$ Conditional dismissals would seldom result in appeals or malpractice suits. Therefore, although the original case would ordinarily continue, there would be an offsetting reduction in the burden on courts if conditional dismissals were used.

2. Deterrence. Unconditional dismissal tends to deter dilatory and disobedient conduct on the part of plaintiffs' attorneys. The coercive effect of conditional dismissal, on the other hand, operates largely after the fact; the threat of conditional dismissal would not be as inhibitory.

(D.C. Cir. 1964); Daley v. County of Butte, 227 Cal. App. 2d 380, 38 Cal. Rptr. 693 (1964). Although notice to an attorney is usually considered notice to his client, if the plaintiff is to be given any real protection by conditional dismissal, he should be personally apprised either of the hearing on the question of dismissal or, in any event, of the conditional dismissal which ensues if unconditional dismissal is inappropriate under the circumstances. It would be a simple matter to require that plaintiff's address be entered somewhere on the complaint even though he has retained counsel.

88 Absenteeism seems to be the most serious problem concerning efficiency, since time is lost forever if the court does not have a chance to reschedule. But the question is not whether to bar the innocent plaintiff or forgive the attorney, for the attorney himself can be penalized either by an assessment of costs, see notes 74-76 supra and accompanying text, or by some other means, see notes $92-97$ infra and accompanying text.

89 This may be either because of res judicata, see note 26 supra, or because the statute of limitations has run, see note 27 supra.

90 See Mr. Justice Black's dissenting opinion in Link, 370 U.S. at 649. Appellate courts as well as trial courts are troubled by congestion. See Wright, The Overloaded Fifth Circuit: $A$ Crisis in Judicial Administration, 42 Tex. L. REv. 949 (1964). Any evaluation of alternative procedures should consider their effects on the judicial system as a whole.

91 The original case after conditional dismissal might often be prosecuted as diligently as the malpractice suit which might replace it if unconditional dismissal were used. Also, the original action will usually be nearer to completion, since some judicial time will often have been expended upon it in pretrial procedures which would not have to be duplicated if the action were continued. 
However, unconditional dismissal is retained in the system suggested in this comment for the situations where deterrence is probably most desirable; ${ }^{92}$ and if costs were frequently assessed against derelict attorneys as in Bardin $v$. Mondon, ${ }^{93}$ the deterrent effect would be increased.

Furthermore, where appropriate, a more severe sanction could be imposed directly upon the attorney in lieu of or in addition to an assessment of costs. Where the problem is disobedience to a court order, the attorney's misconduct may amount to contempt..$^{94}$ If so, a fine could be imposed upon notice and hearing. ${ }^{95}$

In addition to their statutory power to punish for contempt, courts have inherent authority to discipline members of the bar. ${ }^{96}$ Where an attorney has misled his client concerning the status of his case, temporary suspension from the bar might be an appropriate penalty ${ }^{97}$ Also courts might impose a disciplinary fine on attorneys whose misconduct has not amounted to contempt but has nevertheless been reprehensible, or upon attorneys who repeatedly neglect their clients' cases. ${ }^{98}$

Therefore, it is not necessarily true that "complete chaos in judicial proceedings will surely result" unless clients always suffer for their attorneys' neglect. ${ }^{99}$

\section{CONCLUSION}

Unconditional dismissal often deprives an innocent plaintiff of a trial on the merits. The availability of a malpractice suit ameliorates the present law to some extent, but the plaintiff probably bears the loss

92 See notes $80,82-83$ supra and accompanying text.

93 See notes 75-76 supra. Of course, if the plaintiff continues to retain the same lawyer he might surreptitiously shift the assessment to the plaintiff by raising his fee.

94 See Marshall v. Southern Farm Bureau Cas. Co., 36 F.R.D. 186 (W.D. La. 1964); aff'd, 353 F.2d 737 (5th Cir. 1965), cert. denied, 384 U.S. 910 (1966).

95 See 18 U.S.C. \$ 401(3) (1966); FEd. R. CRIM. P. 42(b).

96 The sanctions generally imposed pursuant to this inherent authority are disbarment, temporary suspension, and reprimand. See Smith, Disbarments and Disciplinary Action: The Record for Five Years, 47 A.B.A.J. 363, 364 (1961). Disbarment, which should never be imposed "where any punishment less severe-such as reprimand, temporary suspension, or fine-would accomplish the end desired," Bradley v. Fisher, 80 U.S. (13 Wall.) 335, 355 (1871), is too drastic to be of much use in this context. Reprimand appears to have little or no deterrent effect. See Note, Misconduct of Judges and Attorneys During Trial: Informal Sanction, 49 IowA L. REv. 531, 537 (1964).

97 See Moore v. State Bar, 62 Cal. 2d 74, 396 P.2d 577, 41 Cal. Rptr. 161 (1964); In re Lanza, 24 N.J. 191, 131 A.2d 497 (1957).

08 See Comment, An Attorney Fine: A Sanction to Ensure Compliance With Court Calendar Orders, 30 U. CHI. L. REv. 382 (1963). But see Gamble v. Pope \& Talbot, Inc., 191 F. Supp. 763 (E.D. Pa. 1961), rev'd, 307 F.2d 729 (3d Cir.), cert. denied, 371 U.S. 888 (1962).

99 Barber v. Tuberville, 218 F.2d 34, 38 (D.C. Cir. 1954). 
in many cases. Conditional dismissal would give the non-negligent plaintiff with a viable cause of action an opportunity to protect his interest; at the same time, it would protect the defendant who has not been significantly injured by previous delay from further abuse. If the defendant has incurred costs, reimbursement can be ordered by the court. Although the present law may promote efficiency, it is strikingly indifferent toward the plaintiff's predicament. A conditional dismissal and an assessment of costs against the errant attorney would be an equitable solution where fairness to the defendant does not require a more drastic approach. It is submitted, moreover, that this approach would not seriously decrease the efficiency of the judicial process. 